\title{
EDITORIAL
}

\section{Devolution: a process, not an event}

\author{
Robin McCreadie
}

Early in 2002, I was asked by the then President of the College Professor John Cox to 'take soundings' within the College with regard to matters of devolution. ${ }^{1}$ The topic had arisen partly because of an increase in devolved health powers in the Scottish and Welsh governments; some unease about the relationship between the College in [the Republic of] Ireland and the Irish government; and some unease within the English divisions about their role and purpose.

Before I began the consultation process I reminded myself about the objects and purposes of the College (Box 1) and the functions of its divisions (Box 2). I was struck, first, by the emphasis in the objects and purposes on education, training and research; and, second, by the rather vague functions of the divisions - they seemed merely to be advisory and to be a conduit for the exchange of information.

\section{Consultation}

I consulted widely within the College and made myself available to speak at meetings of various divisions. Four main themes emerged.

\section{The English divisions}

Members in the English divisions look somewhat enviously at Scotland, Ireland and, to a lesser extent, Wales. They perceive organisations with a clear sense of identity, which have administrative support and which are over-represented in the various College structures and committees.

\section{Ireland}

Considerable devolution is already apparent in Ireland, with the creation of the Irish College of Psychiatrists and its associated developments. A

1. 'devolution noun the transfer or delegation of power to a lower level, especially by central government to local or regional administration. formal descent or degeneration to a worse state' (The New Oxford English Dictionary, 1998).

It is my view, and that of almost everyone I spoke to, that devolution does not mean separation.

\section{Box 1 Objects and purposes of the College}

'The objects and purposes for which the College is constituted are to:

(a) advance the science and practice of psychiatry and related subjects;

(b) further public education therein;

(c) promote study and research work in psychiatry and all sciences and disciplines connected with the understanding and treatment of mental disorder in all its forms and aspects and related subjects and publish the results of all such study and research.'

Supplemental Charter, p. 5:3/1

(Royal College of Psychiatrists, 2001)

view expressed by a number of members in Northern Ireland was that they felt 'disadvantaged', as no psychiatrist in Northern Ireland can belong to the Irish College of Psychiatrists. There was a strong feeling in Northern Ireland that there should be a separate Northern Ireland [sic] Division.

\section{Overseas members}

About $15 \%$ of our members work overseas (Table 1 ). Although there are loosely formed overseas groups, there are no overseas divisions. If there were, and if they had responsibilities similar to those of the British Isles' divisions, then the voice of the overseas members could be more clearly heard.

\section{Box 2 The College's divisions}

'Divisions shall, through their Executive Committees, keep Council informed of training and service issues arising in the Division. They shall inform members of the Division of the activities and requirements of the College. Divisions shall represent the College locally and provide professional advice where required.'

Regulations, p. 50: XXIV/A/2 (Royal College of Psychiatrists, 2001)

Robin McCreadie is Director of Clinical Research at Crichton Royal Hospital (Dumfries DG1 4TG, Scotland) and honorary professor at the universities of Glasgow and Aberdeen. 


\section{Table 1 Membership of College divisions (2002)}

Division

Membership

UK Scotland $\quad 871$

Wales 319

Northern Ireland 205

England, by region

Northern \& Yorkshire $\quad 772$

North West 733

Trent 588

West Midlands 545

Eastern 542

London 2033

South East 1006

South West 611

England regional total $\quad \mathbf{6 8 3 0}$

UK total $\mathbf{8 2 2 5}$

Ireland 498

Overseas

Europe 138

The Americas $\quad 455$

Indian subcontinent $\quad 100$

Middle East 106

Oceania 482

Far East 211

Africa

43

Overseas total

1535

No-mail division

111

Total membership

10369

\section{Central structures}

Almost no one was happy with Council. It was seen as being too large and unwieldy (it currently has 61 members). English members believed that too much time was taken up with 'Celtic' matters; Celtic members thought that Council was far too 'Englandoriented'; non-London-based English members thought most topics were 'London-related'.

Both English and Celtic members had reservations about the Court of Electors, which was seen as somewhat shadowy and secretive.

\section{A scoping group}

In November 2002 I submitted a report to the Executive and Finance Committee. The upshot of this was the creation of a 'scoping group', which would look closely at the findings and make recommendations for change.

The vast majority of the people I had consulted and spoken to were keen for change. They wanted to be more involved in College activities and believed that devolution of functions to the divisions would strengthen, not weaken, the College. It was also recognised that devolution is a process, not an event. Change should come, but possibly at a different pace in different parts, with regard to both the divisions and central structures. It was also expected that success would build on success: 'The more you do, the more you'll want to do'.

\section{Proposals of the scoping group \\ Functions and responsibilities of divisions}

It is proposed that each division be responsible for:

- elections of regional advisers, members of the Court of Electors and members of the executive committees of faculties and sections;

- nominations of MRCPsych examiners, assessors on advisory appointment committees, Fellows, and for distinction awards;

- administration and audit of CPD;

- public policy: with a public policy committee in each division to deal with national issues, and a supra-divisional committee in England.

\section{Structural changes in divisions}

It is proposed that each division has full-time administrative support, based within the division's geographical area. The chairman of a division would be a Vice-President of the College. Scotland, Wales, Ireland and Northern Ireland would each have a division, and there would be a reduced number of English divisions and six international divisions (corresponding to the six regional offices of the World Health Organization).

\section{Central structures}

Council and the Executive and Finance Committees should no longer exist in their current form. In their place there should be a single, smaller committee, which would consider issues of a supranational nature. Policy issues would be devolved to divisions.

\section{The future}

These are the proposals. Consultations continue. Some of the proposals can be introduced quickly; others will take time. The end result should be a College more responsive to its members' needs and more able to fulfil its 'objects and purposes'.

\section{Reference}

Royal College of Psychiatrists (2001) Supplemental Charter, Bye-Laws and Regulations (Occasional Paper OP52). London: Royal College of Psychiatrists. 